July 2007

\title{
Gangliocytic paraganglioma: case report and review of the literature
}

Agnes Witkiewicz

Thomas Jefferson University

Avi Galler

Thomas Jefferson University

Charles Yeo

Thomas Jefferson University

Follow this and additional works at: https://jdc.jefferson.edu/surgeryfp

Part of the Surgery Commons

Let us know how access to this document benefits you

\section{Recommended Citation}

Witkiewicz, Agnes; Galler, Avi; and Yeo, Charles, "Gangliocytic paraganglioma: case report and review of the literature" (2007). Department of Surgery Faculty Papers. Paper 9.

https://jdc.jefferson.edu/surgeryfp/9

This Article is brought to you for free and open access by the Jefferson Digital Commons. The Jefferson Digital Commons is a service of Thomas Jefferson University's Center for Teaching and Learning (CTL). The Commons is a showcase for Jefferson books and journals, peer-reviewed scholarly publications, unique historical collections from the University archives, and teaching tools. The Jefferson Digital Commons allows researchers and interested readers anywhere in the world to learn about and keep up to date with Jefferson scholarship. This article has been accepted for inclusion in Department of Surgery Faculty Papers by an authorized administrator of the Jefferson Digital Commons. For more information, please contact: JeffersonDigitalCommons@jefferson.edu. 


\author{
Subject Review:
}

Malignant Gangliocytic Paraganglioma: Case Report and Review of the Literature

\author{
Agnes Witkiewicz, M.D. \\ Avi Galler, M.D. \\ Charles J. Yeo, M.D. \\ Departments of Pathology and Surgery \\ Thomas Jefferson University \\ Philadelphia, Pennsylvania
}

Running Title: Gangliocytic Paraganglioma

\title{
Correspondence
}

Charles J. Yeo, M.D.

Samuel D. Gross Professor and Chair of Surgery

Thomas Jefferson University/Jefferson Medical College

1015 Walnut Street, Suite 620

Philadelphia, PA 19107

Phone - (215) 955-8643

Fax - (215)923-6609

E-mail: charles.yeo@jefferson.edu 


\begin{abstract}
Gangliocytic paraganglioma is a rare tumor which occurs nearly exclusively in the second portion of the duodenum. Generally, this tumor has a benign clinical course, although rarely it may recur or metastasize to regional lymph nodes. Only one case with distant metastasis has been reported. We present a case of duodenal gangliocytic paraganglioma treated first by local resection followed by pylorus-preserving pancreaticoduodenectomy. Examination of the first specimen revealed focal nuclear pleomorphism and mitotic activity, in addition to the presence of three characteristic histologic components: epithelioid, ganglion and spindle cell. In the subsequent pancreaticoduodenectomy specimen, there was no residual tumor identified in the periampullary area, but metastatic gangliocytic paraganglioma was present in 2 of 7 lymph nodes. This case confirms the malignant potential of this tumor. We review the published literature on gangliocytic paragangliomas pursuing a malignant course. We conclude that surgical therapy of these neoplasms should not be limited to local resection, as disease recurrence, lymph node involvement and rarely distant metastasis may occur.
\end{abstract}




\section{INTRODUCTION}

Gangliocytic paraganglioma (GP) is a rare tumor which occurs

nearly exclusively in the second portion of the duodenum $(1,2)$. The lesion was first described by Dahl et al in 1957, and further characterized as a benign nonchromaffin paraganglioma by Taylor and Helwig in $1961(3,4)$. Kepes and Zacharias coined the term "gangliocytic paraganglioma" in 1971, recognizing the features in common with both paraganglioma and ganglioneuroma (5). Generally, this tumor has a benign clinical course, although rarely it may recur or metastasize to regional lymph nodes (6-9).

There has been one report of distant metastases (10). We report a case of a 38 year old female with a periampullary gangliocytic paraganglioma with lymph node metastases, and review the published literature on GPs pursuing malignant course

\section{CASE PRESENTATION}

A 38 year old woman with thalassemia trait presented to a local hospital with right upper quadrant pain. A presumptive diagnosis of hiatal hernia with ulcers was made, and the patient was started on a proton pump inhibitor. Upon further workup, an upper endoscopy revealed a mass in the duodenum, near the ampulla of Vater. After several negative biopsies, she underwent endoscopic excision of the mass, which proved to be a gangliocytic paraganglioma, with extension to the margin. Due to the positive margin status, the patient was referred for surgical opinion and 
regional resection was recommended. Three months following endoscopic resection, the patient underwent pylorus-preserving pancreaticoduodenectomy with standard reconstruction. Following an uneventful recovery, she was discharged from the hospital on the 8th postoperative day.

Pathologic evaluation of the endoscopic ampullectomy specimen showed a $1.5 \mathrm{~cm}$ polypoid tumor in the submucosa with extension to the muscularis propria (Figure 1A). The lesion was non-encapsulated and had an infiltrative margin. The tumor was composed of 3 morphologically distinct cell populations: epithelioid cells, spindle cells and scattered ganglion cells (Figure 1B). The epithelioid cells were arranged in nests and trabeculae, and had granular eosinophilic cytoplasm and nuclei showing mild to moderate atypia (Figure 1C). The spindle cells formed slender fascicles wrapping around nests of epithelioid cells. The ganglion cells had round nuclei with prominent nucleoli and abundant eosinophilic cytoplasm. The mitotic count was 2 per 10 high power fields. Necrosis was not present. In the subsequent pancreaticoduodenectomy specimen, there was no residual tumor identified in the periampullary area, but metastatic gangliocytic paraganglioma was present in 2 of 7 lymph nodes (Figure 1D). The metastatic foci show the presence of the 3 cellular components identified in the primary tumor. Immunohistochemical stains were performed on the metastatic tumor. The chromogranin stain showed positivity in the epithelioid cells, while synaptophysin highlighted epithelioid 
and ganglion cells. The spindle cells stained with $\mathrm{S} 100$ and neurofilament. Cytokeratin and glial fibrillary acidic protein were negative in all 3 cell populations.

\section{DISCUSSION}

Gangliocytic paraganglioma (GP) is usually seen in the periampullary region of duodenum, with rare cases reported in the jejunum, pylorus (1,2), esophagus (11), pancreas (10) and appendix (12). Recently, three cases of pulmonary GP have been reported $(13,14,15)$. The age at presentation ranges from 15-82 years (mean 54), and there is slight male predominance.

Clinically, GPs arising in the gastrointestinal tract present with bleeding, abdominal pain or obstruction; some cases are found incidentally at endoscopy or autopsy (2). In the largest reported series of 51 GPs, abdominal pain was the most common presenting symptom and was usually attributed (like in our case) to ulcer disease (1). The three cases of pulmonary GP reported to date presented with chest pain, pneumonia and Cushing's syndrome, respectively $(13,14,15)$. The tumor is usually unrelated to other diseases although an association with von Recklinghausen disease has been reported $(2,16)$. GP has three characteristic histologic components: epithelioid, ganglion and spindle cell. Recognition of this triad aids diagnosis on routine hematoxylin and eosin sections. The proportion of the three cell types varies in each tumor, but each component shows characteristic immunohistochemical staining similar to those observed in our case (17). 
Theories on the origin of GPs are widely divergent. Studies have not been able to reconcile the combination of endocrine, ganglion, and spindle cells observed in a single tumor. The tumor components are of different embryologic origins, the first being of endodermal origin and the other 2 originating from neural crest tissue. Initially, it was suggested that these tumors were of ectodermal origin, from pluripotent stem cells derived from the neural crest, which were found in Lieberkühn's glands or the celiac ganglion during fetal development (3). Given the presentation of GPs in various sites in the duodenum and its variable histology, some authors have proposed that it originated from an endodermal pluripotent progenitor or stem cell that has the potential for divergent differentiation (16). It was also proposed that GPs were hamartomas of endodermal (epithelial cells) and neuroectodermal (ganglion and spindle cells) origin (17). However, evidence conflicting with the hamartoma theory includes cases such as ours of lymph node and distant metastasis. Most authors consider GPs to be variants of gastrointestinal tract paragangliomas (18). Paragangliomas may differentiate to other neuroectodermal elements, including neurons and Schwann cells (19). Further evidence of potential for divergent differentiation of neoplastic neuroendocrine cells includes the observation that, when stimulated by nerve growth factor, cell cultures from carcinoid tumor or small cell carcinoma differentiate toward neurons (20). 
Most GPs are benign and are amenable to local resection (2). However, rare instances of recurrence, lymph node involvement, and distant metastases have been previously reported (6-10, 21-26). Twelve cases of GPs with malignant features are summarized in Table 1. In eleven cases, lymph node metastases were identified. One patient treated initially by local resection developed bone and liver metastasis 3 months later (10). Outcomes of these twelve cases clearly indicate the rare malignant potential of GP. Furthermore the incidence of malignant cases could be underestimated since majority of the reported as benign GPs cases underwent local resection only, which does not allow examination of lymph nodes. In addition most cases have been published as single case reports, without long term follow up data.

To date, histologic features predicting malignant potential has not been defined, although the presence of nuclear pleomorphism, mitotic activity and infiltrative margin, as seen in our case, raises the concern for aggressive behavior. Since GP may recur or metastasize, pancreaticoduodenectomy with lymph node dissection may be indicated for large lesions with infiltrative margin or lesions with pleomorphism and mitoses. 


\section{References}

1. Burke AP, Helwig EB. Gangliocytic paraganglioma. Am J Clin Pathol 1989;92:1-9.

2. Scheithauer BW, Nora FE, LeChago J, Wick MR, Crawford BG, Weiland LH, Carney JA. Duodenal gangliocytic paraganglioma. Clinicopathologic and immunocytochemical study of 11 cases. Am J Clin Pathol 1986;86:559-565.

3. Dahl EV, Waugh JM, Dahlin DC. Gastrointestinal ganglioneuromas: brief review with report of a duodenal ganglioneuroma. Am J Pathol 1957;33:953-966.

4. Taylor HB, Helwig EB. Benign nonchromaffin paragangliomas of the duodenum. Virchows Arch Pathol Anat Physiol Klin Med 1962;335:356-366

5. Kepes JJ, Zacharias DL. Gangliocytic paragangliomas of the duodenum. A report of two cases with light and electron microscopic examination. Cancer 1971;27:61-7.

6. Sundararajan V, Robinson-Smith TM, Lowy AM. Duodenal gangliocytic paraganglioma with lymph node metastasis: a case report and review of the literature. Arch Pathol Lab Med $2003 ; 127: 139-141$

7. Inai K, Kobuke T, Yonehara S, Tokuoka S. Duodenal gangliocytic paraganglioma with lymph node metastasis in a 17-year-old boy. Cancer 1989;63:2540-2545. 
8. Dookhan DB, Miettinen M, Finkel G, Gibas Z. Recurrent duodenal gangliocytic paraganglioma with lymph node metastases.

Histopathology 1993;22:399-401.

9. Hashimoto S, Kawasaki S, Matsuzuwa K, Marada H, Makuuchi M. Gangliocytic paraganglioma of the papilla of Vater with regional lymph node metastasis. Am J Gastroenterol 1992;87:1216-1218.

10. Henry C, Ghalel-Mechaoui H, Bottero N, Pradier T, Moindrot H. Gangliocytic paraganglioma of the pancreas with bone metastasis. Ann Chir 2003;128:336-338.

11. WeinrachDM, Wang KL, Blum MG, Yelandi AV, Laskin WB. Multifocal presentation of gangliocytic paraganglioma in the mediastinum and esophagus. Hum Pathol 2004;35:1288-1291.

12. Van Eeden S, Offerhaus GJ, Peterse HL, Dingemans KP, Blaauwgeers HL. Gangliocytic paraganglioma of the appendix. Histopathology 1993;63:2540-2545.

13. Hironaka M, Fukayam M, Takayashiki N, Saito K, Sohara Y, Funata N. Pulmonary gangliocytic paraganglioma: case report and comparative immunohistochemical study of related neuroendocrine neoplasms. Am J Surg Pathol 2001;25:688-693.

14. Kee AR, Forrst CH, Brennan BA, Papadimitriou JM, Glancy RJ. Gangliocytic paraganglioma of the bronchus: a case report with follow-up and ultrastructural assessment. Am J surg Pathol $2003 ; 27: 1380-1385$. 
15. Palau MA, Merino MJ, Quezado M. Corticotropin-producing pulmonary gangliocytic paraganglioma associated with Cushing's syndrome. Hum Pathol 2006;37:623-626.

16. Kheir SM, Halpern NB. Paraganglioma of the duodenum in association with congenital neurofibromatosis. Possible relationship. Cancer 1984;53:2491-2496.

17. Perrone T, Sibley RK, Rosai J. Duodenal gangliocyic paraganglioma: An immunohistochemical and ultrastructural study and a hypothesis concerning its origin. Am J Surg Pathol 1985;9:3141.

18. Reed RJ, Caroca PJ Jr. Karkin JC. Gangliocytic paraganglioma. Am J Surg Pathol 1977;1:207-216.

19. Lerman RI, Kaplan ES, Daman L. Ganglioneuroma-paraganglioma of the intradural filum terminale. Case report. J Neurosurg 1972;36:652-658.

20. Tischler AS, Dichter MA, Biales B, DeLellis RA, Wolfe H. Neural properties of cultured human endocrine tumor cells of proposed neural crest origin. Science 1976;192:902-904.

21. Buchler M, Malfertheiner P, Baczako K, Krautzberger W, Beger HG. A metastatic endocrine-neurogenic tumor of the ampulla of Vater with multiple endocrine immunoreaction--malignant paraganglioma? Digestion 1985;31:54-59. 
22. Korbi S, Kapanci Y, Widgren S. Malignant paraganglioma of the duodenum. Immunohistochemical and ultrastructural study of a case. Ann Pathol 1987;7:47-55.

23. Tomic S, Warner T. Pancreatic somatostatin-secreting gangliocytic paraganglioma with lymph node metastases. Am J Gastroenterol 1996;91:607-608.

24. Bucher P, Mathe Z, Buhler L, Chilcott M, Gervaz P, Egger JF, Morel P. Paraganglioma of the ampulla of Vater: a potentially malignant neoplasm. Scand J Gastroenterol 2004;39:291-295.

25. Ljungberg O, Jarnerot G, Rolny P, Wickbom G. Human pancreatic polypeptide (HPP) immunoreactivity in an infiltrating endocrine tumour of the papilla of Vater with unusual morphology. Virchows Arch A Pathol Anat Histol 1981;392:119-126.

26. Wong A, Miller AR, Metter J, Thomas CR Jr. Locally advanced duodenal gangliocytic paraganglioma treated with adjuvant radiation therapy: case report and review of the literature. World J Surg Oncol $2005 ; 3: 15$ 
Table 1. Gangliocytic Paragangliomas with Lymph Node or Distant Metastasis

\begin{tabular}{|c|c|c|c|c|c|}
\hline Author & Treatment & Tumor site & $\begin{array}{l}\text { Nodal } \\
\text { Spread }\end{array}$ & $\begin{array}{l}\text { Distant } \\
\text { Spread }\end{array}$ & $\begin{array}{c}\text { Follow } \\
\text { up }\end{array}$ \\
\hline Burke et al. (1) & $\begin{array}{l}\text { Whipple } \\
\text { procedure }\end{array}$ & Duodenum & Yes & No & $\begin{array}{c}\text { NED } 91 \\
\text { mo }\end{array}$ \\
\hline $\begin{array}{c}\text { Buchler et al } \\
(21)\end{array}$ & $\begin{array}{c}\text { Local } \\
\text { resection }\end{array}$ & $\begin{array}{c}\text { Ampulla of } \\
\text { Vater }\end{array}$ & Yes & No & $\begin{array}{c}\text { NED } 20 \\
\text { mo }\end{array}$ \\
\hline Korbi et al (22) & $\begin{array}{l}\text { Whipple } \\
\text { procedure }\end{array}$ & Duodenum & Yes & No & $\begin{array}{c}\text { Not } \\
\text { known }\end{array}$ \\
\hline Tomic et al (23) & $\begin{array}{l}\text { Whipple } \\
\text { procedure }\end{array}$ & $\begin{array}{l}\text { Head of } \\
\text { pancreas }\end{array}$ & Yes & No & $\begin{array}{c}\text { NED } 19 \\
\text { mo }\end{array}$ \\
\hline $\begin{array}{c}\text { Bucher et al } \\
\text { (24) }\end{array}$ & $\begin{array}{l}\text { Whipple } \\
\text { procedure }\end{array}$ & $\begin{array}{c}\text { Ampulla of } \\
\text { Vater }\end{array}$ & Yes & No & $\begin{array}{c}\text { NED } 40 \\
\text { mo }\end{array}$ \\
\hline $\begin{array}{c}\text { Dookhan et al } \\
(8)\end{array}$ & $\begin{array}{l}\text { Local } \\
\text { resection }\end{array}$ & Duodenum & Yes & No & $\begin{array}{c}\text { Not } \\
\text { known }\end{array}$ \\
\hline Inai et al (7) & $\begin{array}{c}\text { Local } \\
\text { resection* }\end{array}$ & $\begin{array}{c}\text { Ampulla of } \\
\text { Vater }\end{array}$ & Yes & No & $\begin{array}{c}\text { NED } 30 \\
\text { mo }\end{array}$ \\
\hline $\begin{array}{l}\text { Hashimoto et al } \\
\text { (9) }\end{array}$ & $\begin{array}{l}\text { Whipple } \\
\text { procedure }\end{array}$ & $\begin{array}{c}\text { Ampulla of } \\
\text { Vater }\end{array}$ & Yes & No & $\begin{array}{c}\text { NED } 14 \\
\text { mo }\end{array}$ \\
\hline $\begin{array}{c}\text { Ljungberg et al } \\
(25)\end{array}$ & $\begin{array}{c}\text { Local } \\
\text { resection }\end{array}$ & $\begin{array}{c}\text { Ampulla of } \\
\text { Vater }\end{array}$ & Yes & No & $\begin{array}{c}\text { Not } \\
\text { known }\end{array}$ \\
\hline $\begin{array}{c}\text { Sundararajan } \\
(6)\end{array}$ & $\begin{array}{l}\text { Whipple } \\
\text { procedure }\end{array}$ & Duodenum & Yes & No & $\begin{array}{l}\text { NED } \\
9 \text { mo }\end{array}$ \\
\hline Wong (26) & $\begin{array}{l}\text { Whipple } \\
\text { procedure }\end{array}$ & $\begin{array}{c}\text { Ampulla of } \\
\text { Vater }\end{array}$ & Yes & No & $\begin{array}{c}\text { Not } \\
\text { known }\end{array}$ \\
\hline Henry et al(10) & $\begin{array}{l}\text { Whipple } \\
\text { procedure }\end{array}$ & Not known & No & $\begin{array}{l}\text { Liver } \\
\text { Bone }\end{array}$ & $\begin{array}{c}\text { Not } \\
\text { known }\end{array}$ \\
\hline
\end{tabular}

*Whipple procedure after recurrence. NED indicates alive with no evidence of disease; Mo, months. 


\section{Figure Legends}

Figure 1. (A) Submucosal location of the tumor in the periampullary region (H\&E, 10X). (B) The tumor consists of epithelioid cells forming nests, fascicles of spindle cells (arrow) and ganglion-like cells (arrowhead) (H\&E, 20X). (C) Nuclear pleomorphism and mitosis (arrowhead) are present (H\&E, 40X) (D) Metastatic tumor in a lymph node retrieved at pancreaticoduodenectomy, composed of epithelioid and spindle cells(arrowhead) (H\&E, 20X). 